\title{
The agreement of cytomegalovirus (CMV) serology examination and CMV polymerase chain reaction of liver tissue in infants with cholestasis
}

\author{
*Bagus Setyoboedi ${ }^{1}$, Reny Widayanti ${ }^{1}$, Sjamsul Arief $^{1}$, Dwiyanti Puspitasari ${ }^{1}$, Rendi Aji Prihaningtyas $^{1}$
}

Sri Lanka Journal of Child Health, 2021; 50(1): 43-48

\begin{abstract}
Introduction: The incidence of cholestasis in infancy is associated with congenital or viral infection. Commonest cause is Cytomegalovirus (CMV) infection. In Indonesia, diagnosis of cholestasis due to CMV infection is still not optimal because the support of virological examination is still limited, so serological examination is an option.
\end{abstract}

Objective: Analysing the agreement of CMV IgG or IgM serological examination and CMV polymerase chain reaction (PCR) examination of liver tissue in infants with cholestasis

Method: This is an analytic observational research using cross sectional design. Samples were infants with cholestasis, 1-12 months of age, in the Department of Child Health, Dr. Soetomo General Hospital, who met the inclusion criteria. Samples were taken from December 2017- May 2018. Liver biopsy was done in Department of Child Health, Dr. Soetomo Hospital. CMV PCR examination of liver tissue was carried out in the Tropical Disease Laboratory at Airlangga University. Data were analysed by calculating the kappa coefficient CMV $\mathrm{IgG}$ or IgM serology examination and CMV PCR examination of liver tissue.

Results: There were 30 infants with cholestasis, consisting of $16(53 \%)$ boys and $14(47 \%)$ girls. Positive CMV IgG was found in 28 subjects and CMV IgM was found in 15 subjects. CMV PCR was positive in $20(67 \%)$ subjects. The most common age range with positive CMV IgG and IgM as well as CMV PCR was 1-3 months. Agreement of CMV

\begin{tabular}{l}
\hline${ }^{1}$ Airlangga University, Indonesia \\
${ }^{*}$ Correspondence: bagus.setyoboedi@fk.unair.ac.id
\end{tabular}

https://orcid.org/0000-0002-3923-6913

(Received on 26 February 2020: Accepted after revision on 20 March 2020)

The authors declare that there are no conflicts of interest

Personal funding was used for the project.

Open Access Article published under the Creative

Commons Attribution CC-BY (C) (i) License
IgG compared to CMV PCR of liver tissue showed weak result with kappa value of 0.25 . The agreement of CMV IgM compared to CMV PCR of liver tissue was not found with kappa value 0.00 .

Conclusions: In infants with cholestasis, there is no agreement for CMV serological examination with CMV PCR of liver tissue. CMV serologic examination cannot replace CMV PCR of liver tissue to determine the presence of $\mathrm{CMV}$ virus in infant with cholestasis.

DOI: http://dx.doi.org/10.4038/sljch.v50i1.9401

(Key words: cholestasis, CMV serology, CMV PCR liver tissue, agreement, infant).

\section{Introduction}

Cholestasis is a decrease or obstruction of bile flow at each level to the extrahepatic biliary tract and duodenum ${ }^{1}$. Cholestasis is found in 1 in 2500 births $^{2}$. Incidence of cholestasis in infancy is associated with congenital or viral infection. Commonest cause is Cytomegalovirus (CMV) infection. Research conducted in Brazil on 76 infants with cholestasis showed $29.4 \%$ positive for CMV serology in intrahepatic cholestasis and $28.5 \%$ positive for CMV serology in extrahepatic cholestasis ${ }^{3}$. CMV infection is diagnosed in neonates by isolating the virus from urine, detecting $\operatorname{IgM}$ in blood, detecting CMV antigen in blood and identifying CMV-DNA by polymerase chain reaction (PCR) ${ }^{4}$. CMV-DNA can be taken from blood or tissue ${ }^{5}$.

Research conducted in Brazil showed a positive frequency of CMV-DNA of $34.3 \%$ of 35 samples of liver tissue examined ${ }^{6}$. Research in Poland in nine children with cholestasis showed 9 CMV IgG positive, $4 \mathrm{CMV}$ IgM positive, and $9 \mathrm{CMV}$ DNA positive in the blood but on immunohistochemistry and molecular examination in liver biopsy tissue, CMV was not found ${ }^{7}$. Research in Brazil showed that in comparison with PCR, serology had a low sensitivity $(33.3 \%)$ and a low positive predictive value $(28.6 \%)^{8}$. In Indonesia, diagnosis of cholestasis due to CMV infection is still not optimal because the support of virological examination is still limited, so serological examination is an option. 


\section{Objectives}

Analysing the agreement of CMV IgG or $\operatorname{IgM}$ serological examination and CMV PCR examination of liver tissue in infants with cholestasis

\section{Method}

This is an analytic observational research using cross sectional design. Subjects were 1-12 months old infants with cholestasis in the Department of Child Health, Dr. Soetomo General Hospital, who met the inclusion criteria. Samples were taken during a 6 month period from December 2017-May 2018.

Ethical issues: Ethical approval was obtained from the Ethics Committee of Dr. Soetomo General Hospital (ERC No. 729/Panke. KKE/XII/2017). Parental written informed consent was obtained prior to data collection.

Total sampling was performed in this study. Inclusion criteria were infants with cholestasis 1-12 months of age. The exclusion criteria were septicaemia, HIV infection, miliary tuberculosis, severe malnutrition, thrombocytopenia, prolonged clotting time, ascites and a history of using immunosuppressants including steroids and cytostatic agents. Liver biopsy was carried out in the Department of Child Health, Dr. Soetomo General Hospital. Serology examination was carried out in the clinical pathology laboratory in the Dr. Soetomo General Hospital. CMV PCR examination of liver tissue was carried out in the Tropical Disease Laboratory at Airlangga University. Descriptive statistics and calculating the kappa coefficient CMV IgG or IgM serology examination and CMV PCR examination of liver tissue were done.

\section{Results}

During the 6 month period, 33 subjects were sampled, 30 subjects met the inclusion criteria and 3 subjects were excluded, 2 with severe infection (sepsis) and 1 with ascites. The basic characteristics of the sample are shown in Table 1. The average age in this study was 3.6 months.

Based on the results of CMV serology, out of 30 study subjects, CMV IgG was positive in 28 patients, and CMV IgM was positive in 15 patients. Age distribution based on CMV serology results shows that the most common age range with CMV IgG and CMV IgM positive is at 1-3 months of age (Figure 1).
Table 1: Basic characteristics of the sample $(n=30)$

\begin{tabular}{|c|c|}
\hline Variable & Result \\
\hline $\begin{array}{l}\text { Sex }-n(\%) \\
\text { Male } \\
\text { Female }\end{array}$ & $\begin{array}{l}16(53) \\
14(47)\end{array}$ \\
\hline $\begin{array}{l}\text { Age in months }-n(\%) \\
1-3 \\
4-6 \\
7-9 \\
10-12 \\
\end{array}$ & $\begin{array}{l}20(66.7) \\
06(20.0) \\
02(06.7) \\
02(06.7)\end{array}$ \\
\hline$A S T$ in $I U-$ Mean (SD) & $221.7(153.3)$ \\
\hline$A L T$ in IU - Mean (SD) & $161.4(86.5)$ \\
\hline Direct bilirubin in $m g / d l$ Mean (SD) & $8.16(4.51)$ \\
\hline Total bilirubin in mg/dl Mean (SD) & $11.11(5.77)$ \\
\hline
\end{tabular}

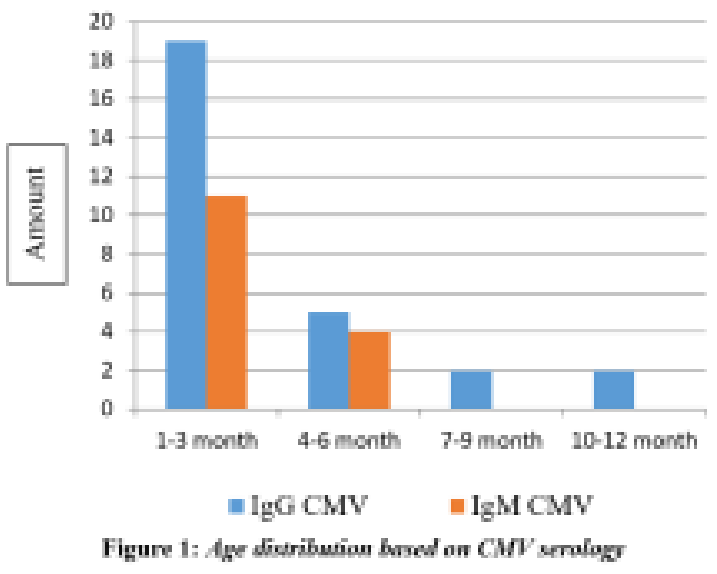

Based on CMV PCR results of liver tissue, CMV PCR was positive in $20(67 \%)$ and CMV PCR was negative in $10(33 \%)$. The most positive CMV PCR was found in the 1-3 month age range in $15(75 \%)$ subjects (Figure 2).

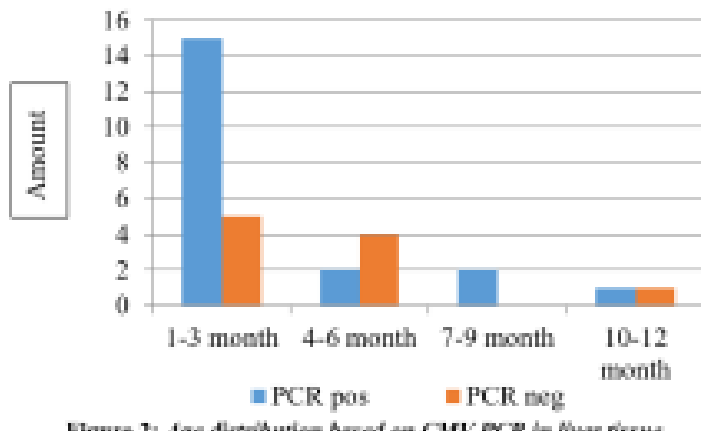

From CMV serologic examination compared with CMV PCR liver tissue was obtained, from 28 subjects with positive CMV IgG, CMV PCR positive liver tissue as much as $20(71.4 \%)$. Based on CMV IgM results compared to CMV PCR liver tissue, from 15 subjects with positive CMV IgM, positive CMV PCR of liver tissue as many as 10 (66.7\%) subjects (Table 2). 
Table 2: Results between CMV serology and CMV PCR liver tissue

\begin{tabular}{|c|c|c|c|c|}
\hline \multicolumn{2}{|c|}{ Variable } & \multicolumn{2}{|c|}{ PCR CMV } & \multirow{3}{*}{$\begin{array}{c}\text { Total } \\
02 \\
\end{array}$} \\
\hline & & \multirow{2}{*}{$\begin{array}{c}\text { Negative } \\
02\end{array}$} & \multirow{2}{*}{$\begin{array}{c}\text { Positive } \\
0\end{array}$} & \\
\hline & Negative & & & \\
\hline $\operatorname{lgGCMV}$ & Positive & 08 & 20 & 28 \\
\hline \multirow{2}{*}{ IgM CMV } & Negative & 05 & 10 & 15 \\
\hline & Positive & 05 & 10 & 15 \\
\hline
\end{tabular}

The agreement of CMV IgG compared to CMV PCR of liver tissue obtained a weak agreement with kappa value of 0.25 . The agreement of CMV $\operatorname{IgM}$ compared to CMV PCR of liver tissue was not in agreement with a kappa value of 0.00 (Table 3 ).

Table 3: Results of kappa suitability between CMV serology and CMV PCR liver tissue based on age

\begin{tabular}{|l|c|c|}
\hline \multirow{2}{*}{ Age } & IgG CMV with PCR CMV & IgM CMV with PCR CMV \\
\cline { 2 - 3 } & Kappa & Kappa \\
\hline $1-3$ months & 0.273 & 0.053 \\
\hline $1-4$ months & 0.362 & 0.015 \\
\hline $1-6$ months & 0.272 & 0.031 \\
\hline $1-12$ months & 0.250 & 0.000 \\
\hline
\end{tabular}

In terms of age, at 1-3 months and 1-4 months of age, CMV IgG compared to CMV PCR liver tissue had a weak agreement with kappa values of 0.273 and 0.362 . At the age of 1-6 months also CMV IgG compared to CMV PCR liver tissue had a weak agreement with kappa value 0.272 (Table 3 ).

Based on the sensitivity test and specificity test $\mathrm{IgG}$ CMV against CMV PCR, sensitivity was $100 \%$, specificity was $20 \%$, positive predictions were $71.4 \%$, negative predictions were $100 \%$ and accuracy was $73.3 \%$. Whereas for IgM CMV against CMV PCR, sensitivity was $50 \%$, specificity was $50 \%$, positive predictions were $66.7 \%$, negative predictions were $33.4 \%$ and accuracy was $50 \%$.

\section{Discussion}

From this study, the age range in as many as 20 (66.7\%) subjects, was 1-3 months. The mean age of the study population was 3.6 months. In research conducted in Brazil, the median age of subjects at the first visit was 82.5 days ( \pm 3 months $)^{6}$. In a study conducted in India, in 101 infants with neonatal cholestasis, the mean age of the subjects was $2.8 \pm$ 1.7 months $^{9}$. In another study, the average age at time of liver biopsy was $2.5 \pm 1$ month $^{10}$. In this study there were $53 \%$ males. Studies by Liberek (2002), Brandao (2009) and Goel (2018) also showed greater male prevalence ${ }^{8,10,11}$. In this study, the mean AST and ALT values were $221.7 \mathrm{mg} / \mathrm{dl}$ and $161.4 \mathrm{mg} / \mathrm{dl}$ respectively. A study by Liberek (2002) had AST $156 \mathrm{mg} / \mathrm{dl} /$ ALT $169 \mathrm{mg} / \mathrm{dl}$, a study by Talachian (2014) had AST $280 \mathrm{mg} / \mathrm{dl} /$ ALT 238 $\mathrm{mg} / \mathrm{dl}$ and a study by Sira (2016) had AST $134 \mathrm{mg} / \mathrm{dl}$ / ALT $230 \mathrm{mg} / \mathrm{dl}^{11,12,13}$.

From the 30 study subjects, CMV IgG was positive in $28(93 \%)$ and CMV IgM was positive in 15
(50\%). Research in Brazil on 76 subjects with neonatal cholestasis was divided into 2 groups, intrahepatic cholestasis (34) and extrahepatic cholestasis (42); in the intrahepatic cholestasis group, CMV IgM was positive in $29.4 \%$, while in the extrahepatic cholestasis group, CMV IgM was positive in $28.5 \%{ }^{3}$. In the study conducted in Poland, all 9 subjects with cholestasis were CMV IgG positive and 4 were CMV IgM positive ${ }^{7}$. In an African study of 78 infants with prolonged jaundice, 72 (92.3\%) were CMV IgG positive and 31 (39.7\%) were CMV IgM positive; the $92.3 \%$ positive CMV $\mathrm{IgG}$ is likely due to maternal IgG transfer via the placenta or IgG production because the baby is infected, even though $39.7 \%$ positive for $\operatorname{IgM}$ in the baby, presumably because there was a possibility of infection in the uterus ${ }^{14}$. CMV $\mathrm{IgG}$ is useful to determine whether the patient has been infected with CMV in the past, whilst IgM antibodies indicate an acute condition or new infection ${ }^{5}$.

In the current study, the highest number of positive CMV IgG and IgM subjects were found in the 1-3 month age range. Research in China showed that primary infection with CMV in children occured in the age range 1-3.5 months and that there was very high anti-CMV IgG seroprevalence in young infants ( $<6$ months) due to persistent maternal antibodies ${ }^{15}$. Generally, moderate to high levels of IgM antibodies can be detected at 1-3 months after the onset of infection, after which IgM levels begin to fall but remain positive for more than 9 months after primary infection ${ }^{16}$.

In our study of 30 subjects, 20 (67\%) were liver tissue CMV PCR positive. These results indicate high CMV frequency in infants with cholestasis. In a study in Taiwan, 26 liver tissue subjects with 
biliary atresia were positive for HCMV DNA in liver tissue with PCR of $2(7.6 \%)^{17}$. In research from Brazil, from 33 liver tissue in subjects with extrahepatic cholestasis, 9 (27.3\%) subjects with PCR were positive for HCMV DNA ${ }^{6}$. Research in India, from 31 subjects with neonatal cholestasis, found positive CMV PCR liver tissue with PCR in $16(52 \%)^{10}$. Variations in CMV PCR results in liver tissue may be explained because of the few patients involved in study as well as the geographic variation of subjects ${ }^{18}$.

CMV PCR positive liver tissue was mostly found in the 1-3-month age range. Research in India on 31 infants with neonatal cholestasis, where the average age at the time of liver biopsy was $2.5 \pm 1.0$ months, positive CMV PCR was $16(52 \%)^{10}$. CMV serological examination compared with CMV PCR of liver tissue, from 28 subjects with positive CMV IgG, 20 positive PCR (71.4\%) subjects. CMV IgG compared to CMV PCR obtained a weak agreement with a kappa value of 0.25 . Research conducted in India $26 \mathrm{CMV}$ IgG positive subjects, 15 (58\%) positive CMV PCR liver tissue with a kappa 0.2 value $^{10}$. In the Brazilian study, $9 \mathrm{CMV}$ IgG positive subjects, 3 subjects were positive for HCMV DNA. CMV IgG represents the presence of transplacental maternal $\mathrm{IgG}^{6}$.

CMV IgM results compared to CMV PCR of liver tissue, from 15 subjects with positive CMV IgM, $66.7 \%$ positive PCR subjects. In this study, CMV IgM compared with CMV PCR did not obtain agreement with kappa value 0.00. Research in Poland, in 9 children with cholestasis, obtained a weak correlation between positive serological results and virus detection in liver tissue ${ }^{7}$. Other studies have shown a positive association between CMV IgM and CMV PCR in liver tissue even though the relationship was very weak. It is suspected that CMV IgM is a poor indicator of the presence or absence of CMV in liver tissue ${ }^{10}$. In infants with CMV serology positive but liver tissue PCR negative, possibly at the time of the study, subjects passed the acute phase of hepatitis due to CMV where the CMV virus was eliminated from liver tissue by the host immune system or CMV infection may be outside liver tissue or hepatitis caused by other aetiologies. Infants with positive HCMV DNA with PCR on liver tissue but negative CMV serology may not produce enough antibodies for some unknown reason ${ }^{17}$.

This study showed that at the age of 1-3 months, 14 months, 1-6 months and 1-12 months, CMV IgG compared to CMV PCR liver tissue, obtained a weak agreement. There was no agreement obtained in CMV IgM in that age range. Other studies have shown that serological examination has weak accuracy to detect active CMV virus infections ${ }^{6}$. There was weak correlation between positive serology and detection of CMV virus in liver tissue ${ }^{7}$. CMV blood serology or PCR is not an accurate marker for CMV infection in liver tissue ${ }^{10}$. CMV IgM and CMV IgG serology examination is not recommended for diagnosing CMV infection in infants. CMV IgG positivity reflects IgG antibodies obtained from the mother through the placenta and not diagnosis of CMV infection. Maternal $\mathrm{IgG}$ antibodies can last up to 18 months in infants. IgG antibodies that remain in infants cannot distinguish congenital, natal or postnatal infections ${ }^{19}$.

In this study, CMV IgM sensitivity to CMV PCR liver tissue was $50 \%$, specificity $50 \%$, accuracy $50 \%$, positive predictive value $66.7 \%$ and negative predictive value $33.4 \%$. Other studies also showed CMV IgM sensitivity to CMV PCR liver tissue was $69 \%$ and specificity was $61 \%{ }^{10}$. Research in Brazil showed CMV PCR of liver tissue compared to serology with sensitivity of $54 \%$, specificity of $61 \%$ and accuracy of $59 \%{ }^{6}$. Compared to PCR, serology has a high accuracy of $82.4 \%$, sensitivity of $33.3 \%$, specificity of $88.9 \%$, positive predictive value of $28.6 \%$, and negative predictive value of $90.01 \%{ }^{8}$. Examination of CMV IgM antibodies for primary infection has less specificity, because $\operatorname{IgM}$ can be positive in active CMV infection ${ }^{5}$. In patients with positive CMV IgM but negative DNA PCR, results are likely to be due to false positive results from IgM. False positives can be secondary to the presence of rheumatoid factors (infant IgM against maternal $\mathrm{IgG}$ ) or cross-reaction with herpesviruses. In patients with IgM negative but positive PCR DNA, results are likely to be due to false negative. False negative results are likely secondary due to competition between high maternal IgG antibody levels and relatively low infant IgM levels ${ }^{6}$.

One limitation of this study is that the biopsy sample was taken with a special needle biopsy on the liver tissue so that the sample obtained was not as good as if the sample was taken during surgery. Ideally, samples should be taken from the bile duct tissue during Kasai surgery. Another drawback of this study is not to examine the types of intrahepatic or extrahepatic cholestasis. The results of this study found no agreement of CMV serological examination and CMV PCR liver tissue in infant cholestasis.

\section{Conclusions}

In infants with cholestasis, there was no agreement for CMV IgM examination with CMV PCR of liver tissue. However, for CMV IgG with CMV PCR of liver tissue, there was low agreement. Serologic 
examination of CMV IgG or IgM is not sensitive and specific, and cannot replace CMV PCR of liver tissue to detect the presence of CMV virus in infant cholestasis.

\section{Acknowledgements}

The authors thank to Dr. Soetomo General Hospital, Surabaya for supporting this study.

\section{References}

1. Girard M, Lacaille F. Diagnosis of neonatal cholestasis. Annales Nestle 2008; 66: 10920 .

https://doi.org/10.1159/000147408

2. Suchy FJ. Neonatal cholestasis. Pediatrics in Review 2004; 25(11): 388-96. https://doi.org/10.1542/pir.25-11-388 PMid: 15520084

3. Oliviera NL, Kanawaty FR, Costa S, Hessel G. Infection by cytomegalovirus in patients with neonatal cholestasis. Arquivos de Gastroenterologia 2002; 39(2): 132-6.

https://doi.org/10.1590/S00042803200200 0200012

PMid: 12612719

4. Bhatia P, Narang A, Minz RW.. Neonatal cytomegalovirus infection: diagnostic modalities available for early disease detection. Indian Journal of Pediatrics 2010; 77: 77-9.

https://doi.org/10.1007/s12098-009-02552

PMid: 19936660

5. Ross S, Novak Z, Pati S, Boppana S. Diagnosis of cytomegalovirus infections. Infectious Disorders Drug Targets 2011; 11: 466-74.

https://doi.org/10.2174/187152611797636 703

PMid: 21827433 PMCid: PMC3730495

6. De Tommaso AM, Andrade PD, Costa SC, Escanhoela CA, Hessel G. High frequency of human cytomegalovirus DNA in the liver of infants with extrahepatic neonatal cholestasis. BMC Infectious Diseases 2005; 5: 108.

https://doi.org/10.1186/1471-2334-5-108

PMid: 16321152 PMCid: PMC1315325

7. Pawłowska JE, Dorota G, Irena J, Przemysław K, Bożena C, Katarzyna D..
The role of cytomegalovirus infection in pathogenesis of neonatal cholestasis. Experimental and Clinical Hepatology 2010; 6: 25-9.

8. Brandao MA, Andrade PD, Costa S, Escanhoela C, Vassallo J, Porta G, et al.. Cytomegalovirus frequency in neonatal intrahepatic cholestasis determined by serology, histology, immunohistochemistry, and PCR. World Journal of Gastroenterology 2009; 15: 3411-6. https://doi.org/10.3748/wjg.15.3411 PMid: 19610143 PMCid: PMC2712903

9. Poddar U, Thapa BR, Das A, Bhattacharya A, Rao KLN, dan Singh K. Neonatal cholestasis: differentiation of biliary atresia from neonatal hepatitis in a developing country. Acta Pcediatrica 2009; 98: 12604.

https://doi.org/10.1111/j.16512227.2009.0 1338.x

PMid: 19469771

10. Goel A, Chaudhari S, Sutar J, dan Bhonde G. Detection of cytomegalovirus in liver tissue in infants with neonatal cholestasis. Pediatric Infectious Disease Journal 2018; 37(7): 632-6.

https://doi.org/10.1097/INF.00000000000 01889

PMid: 29389827

11. Liberek A, Rytlewska M, Sidorkiewicz AS. Cytomegalovirus disease in neonates and infants - clinical presentation, diagnostic and therapeutic problems - own experience. Medical Science Monitor 2002; 8: 815-20.

12. Talacian E, Bidari A, Mehrazma M, Nickkhah N. Biopsy-driven diagnosis in infants with cholestatic jaundice in Iran. World Journal of Gastroenterology 2014; 20(4): 1048-53. https://doi.org/10.3748/wjg.v20.i4.1048 PMid: 24574777 PMCid: PMC3921528

13. Sira MM, Sira AM, Elhenawy IA, Khalil FO. Prevalence of serological markers of $\mathrm{TORCH}$ infections in biliary atresia and other neonatal cholestatic disorders. Available from: https://www.peertechz.com/articles/OJPC H-2-110.php

14. Goedhals D, Kriel J, Hertzog MI, Janse van Rensburg MN. Human cytomegalovirus 
infection in infants with prolonged neonatal jaundice. Journal of Clinical Virology 2008; 43: 216-8.

https://doi.org/10.1016/j.jcv.2008.06.001

PMid: 18619898

15. Chen J, Hu L, Wu M, Zhong T, Zhou Y-H, $\mathrm{Hu} \mathrm{Y}$. Kinetics of $\mathrm{IgG}$ antibody to cytomegalovirus (CMV) after birth and seroprevalence of anti-CMV IgG in Chinese children. Virology Journal 2012; 9: Article number 304(2012).

https://doi.org/10.1186/1743-422X-9-304

PMid: 23228149 PMCid: PMC3544651

16. Revello MG, Gerna G. Diagnosis and management of human cytomegalovirus infection in the mother, fetus, and newborn infant. Clinical Microbiology Reviews 2002; 15: 680-715.

https://doi.org/10.1128/CMR.15.4.680-

715.2002

PMid: 12364375 PMCid: PMC126858
17. Chang MH, Huang HH, Huang ES, Kao CL, Hsu HY, Lee CY. Polymerase chain reaction to detect human cytomegalovirus in livers of infants with neonatal hepatitis. Gastroenterology 1992; 103: 1022-5. https://doi.org/10.1016/00165085(92)9003 $8-\mathrm{Z}$

18. El-Araby HA, Ghoneim EM, El-Rahman MH. Cytomegalovirus frequency in neonates with biliary atresia. Egyptian Journal of Medical Microbiology 2010; 19(2), 25-32.

19. Stehel EK, Sánchez PJ. Cytomegalovirus infection in the fetus and neonate. NeoReviews 2005; 6: e38-e45. https://doi.org/10.1542/neo.6-1-e38 